\title{
FIBRILASI ATRIAL DARI SUDUT PANDANG BIOFISIKA
}

\author{
${ }^{1}$ Indra N. S. Ruray \\ ${ }^{2}$ Vennetia R. Danes \\ ${ }^{2}$ Fransiska Lintong
}

\author{
${ }^{1}$ Kandidat Skripsi Fakultas Kedokteran Universitas Sam Ratulangi Manado \\ ${ }^{2}$ Bagian Fisika Fakultas Kedokteran Universitas Sam Ratulangi Manado \\ E-mail: nilamsariruray@ rocketmail.com
}

\begin{abstract}
Atrial fibrillation (AF) is the most common type of arrhythmia found in daily practices. Moreover, AF is one of the risk factors of emboli stroke and myocardial ischemia in patients with coronary heart diseases. From the biophysics perspective, alterations in ion currents (especially $\mathrm{K}^{+}$) that play some important role in the occurence of action potential can lead to an arrhythmia state. Mutations of genes S140G and V141M that create slow activation of ion channels can participate in the occurence of AF.
\end{abstract}

Keywords: atrial fibrillation, arrhythmia, biophysics, heart disease.

\begin{abstract}
Abstrak: Fibrilasi atrial (FA) merupakan bentuk aritmia yang paling sering dijumpai dalam praktek sehari-hari. FA merupakan salah satu faktor risiko yang menyebabkan stroke emboli, dan dapat mencetuskan gejala iskemik pada kasus dengan dasar penyakit jantung koroner. Ditinjau dari sudut biofisika, gangguan terhadap arus ion (terutama ion $\mathrm{K}^{+}$) yang berperan penting dalam menimbulkan potensial aksi bagi jantung, dapat memicu terjadinya aritmia jantung. Mutasi gen S140G dan V141M yang menyebabkan pengaktifan lambat dari saluran ion turut berperan dalam terjadinya FA.
\end{abstract}

Kata kunci: fibrilasi atrial, aritmia, biofisika, penyakit jantung.

Fibrilasi Atrial (FA) merupakan bentuk aritmia yang paling sering dijumpai dalam praktek sehari-hari dan paling sering menjadi penyebab seseorang harus menjalani perawatan di rumah sakit. Walaupun bukan merupakan keadaan yang mengancam jiwa secara langsung, tetapi FA berhubungan dengan peningkat-an angka morbiditas dan mortalitas. Prevalensi FA semakin meningkat bersamaan dengan peningkatan populasi usia lanjut dan insiden penyakit kardiovaskular. Saat ini FA mengenai 2,2 juta individu di Amerika Serikat, setiap tahun ditemukan 160.000 kasus baru, dan diperkirakan akan meningkat 2,5 kali pada tahun 2050. Jumlah tersebut di bawah angka sesungguhnya karena banyak kasus yang asimtomatik. Pada usia di bawah 50 tahun prevalensi FA kurang dari $1 \%$ dan meningkat lebih dari $9 \%$ pada usia 80 tahun. FA lebih banyak dijumpai pada lakilaki dibandingkan perempuan.

Penyebab tersering dari fibrilasi atrium ialah pembesaran atrium akibat gangguan fungsi katup jantung atau gagal jantung sehingga darah menumpuk di dalam atrium, yang berakibat lanjut terjadinya dilatasi atrium. Keadaan ini disertai kegagalan fungsi atrium sebagai pompa primer untuk memompakan darah ke dalam ventrikel sehingga efisiensi pompa ventrikel pun

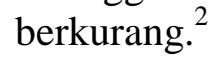

Secara klinis FA praktis tidak dapat dideteksi, dan nanti diketahui dari gambaran elektrokardiogram (EKG). Pemeriksaan EKG dapat dilakukan pada saat menjalani general check-up maupun pada saat menderita penyakit tertentu dengan prosedur 
pemeriksaan yang memerlukan pemeriksaan EKG. Pada setiap kasus FA perlu diberitahukan tentang kondisi jantungnya, sekaligus program pengobatan dan tujuan program pemeriksaan. ${ }^{2}$

FA merupakan aritmia jantung yang paling umum berkelanjutan dan merupakan faktor risiko kematian yang paling sering. FA juga merupakan faktor risiko independen untuk terjadinya stroke iskemik. Umumnya FA terkait dengan stroke karena emboli trombus biasanya terbentuk di atrium kiri yang menyebabkan emboli oklusi dari arteria serebral utama. FA merupakan masalah yang perlu segera diobati untuk mencegah dampaknya terhadap mortalitas karena komplikasi yang parah seperti disfungsi hemodinamik dan stroke. ${ }^{3}$

FA bisa terjadi simtomatik maupun asimtomatik. Gejala-gejala FA sangat bervariasi tergantung dari kecepatan laju irama ventrikel, lamanya $F A$, dan penyakit yang mendasarinya. Sebagian kasus mengeluh berdebar-debar, nyeri dada terutama saat beraktivitas, sesak napas, cepat lelah, sinkop, atau gejala tromboemboli. FA dapat mencetuskan gejala iskemik pada FA dengan dasar penyakit jantung koroner. Fungsi kontraksi atrial yang sangat berkurang pada FA akan menurunkan curah jantung dan dapat menyebabkan terjadi gagal jantung kongestif pada pasien dengan disfungsi ventrikel kiri. ${ }^{3}$

\section{BAHASAN}

Detak jantung normal di mulai di nodus sinoatrial (SA) sejak sel-sel di daerah tersebut secara normal mencapai aktivitas pacemaker tercepat. Polarisasi diastolik maksimal dari sel ini sekitar 50$60 \mathrm{mV}$ dan depolarisasi pacemaker yang bertahap mencetuskan potensial aksi dengan kenaikan yang pelan dengan akibat perambatan lokal yang lambat.

Saluran $\mathrm{K}^{+}$berperan penting dalam depolarisasi sedangkan saluran $\mathrm{Na}^{+}$bersifat inaktif dan tidak berpartisipasi pada fase depolarisasi cepat. Gangguan arus ion terutama ion $\mathrm{K}^{+}$sangat berperan dalam menyebabkan aritmia jantung. Adanya mutasi gen S140G dan V141M yang menyebabkan pengaktifan lambat dari saluran ion juga turut berperan dalam terjadinya FA.

Pada nodus atrioventrikular (AV), potensial aksi menyerupai nodus SA. Durasi potensial aksi yang terjadi di miosit mempunyai dua fungsi, yaitu: 1) melindungi re-eksitasi elektrik dengan menjaga depolarisasi membran. Penghambatan ini menyimpangkan perkembangan jalan konduksi; 2) memungkinkan otot jantung untuk berelaksasi sebelum detakan berikutnya. Hal ini juga mencegah tetanisasi otot jantung, yang tidak menguntungkan bagi fungsi jantung yang berhubungan dengan fungsi otot skeletal. Dari nodus SA, gelombang tersebut melewati otot atrium dan nodus AV dimana konduksi melambat secara progesif dari atrium ke nodus sentral (0,01-0,05 $\mathrm{m} /$ detik) sebelum menjadi sedikit cepat melewati bagian akhir nodus. Setelah gelombang tersebut mencapai ikatannya, cabang dari ikatannya, dan serat purkinje, perambatannya menjadi sangat cepat melewati otot ventrikel (0,3-1 $\mathrm{m} /$ detik). ${ }^{4}$

Aksi ritme jantung dikontrol oleh sinyal yang dimulai dari stimulasi spontan miosit khusus di atrium kanan. Sel-sel ini menyusun nodus SA (pacemaker). Nodus SA berdenyut dengan interval teratur sekitar $72 \mathrm{x} /$ menit. Walaupun begitu denyutan tersebut bisa meningkat atau menurun oleh pengaruh saraf dari luar ke jantung yang berespon terhadap permintaan darah oleh tubuh sesuai dengan stimulusnya. Sinyal elektrik dari nodus SA memulai depolarisasi dari saraf dan otot kedua atrium, menyebabkan atrium berkontraksi dan memompakan darah ke ventrikel. Selanjutnya, pada repolarisasi atrium, sinyal elektrik kemudian melewati nodus SA, yang memulai depolarisasi dari ventrikel kiri dan kanan, dan menyebabkan kedua ventrikel berkontraksi dan memompakan darah ke paru-paru dan sirkulasi tubuh. Saraf dan otot ventrikel kemudian berepolarisasi dan selanjutnya terjadi hal seperti di atas lagi. ${ }^{4}$

Saraf dan otot jantung dapat di anggap sebagai sumber tertutup elektrik di kon- 
duktor elektrik; oleh karena itu tidak lah praktis bila dilakukan pengukuran sinyal elektrik jantung secara langsung. Informasi diagnosis bisa didapatkan dengan memeriksa pada tempat-tempat yang berbeda dari permukaan tubuh atau dada. ${ }^{5}$

Depolarisasi dan repolarisasi otot jantung menyebabkan arus listrik mengalir di dalam tubuh, menimbulkan potensial listrik sampai di kulit. Dengan alat elektrokardiogram (EKG), dapat dilakukan perekaman potensial listrik di antara dua titik yang terletak di berbagai lokasi di permukaan tubuh. $^{6}$

FA juga berhubungan dengan keadaan protrombin yang akan menyebabkan disfungsi endotelial. Pasien dengan FA paroksismal mempunyai disfungsi endotel, dan hal tersebut meningkatkan risiko tromboemboli serta memperburuk prognosis pasien tersebut. Disfungsi endotel diyakini sebagai langkah awal terjadinya aterosklerosis dan beberapa penelitian telah mengevaluasi adanya hubungan antara FA dengan disfungsi endotel. ${ }^{7}$

Sistem pemetaan elektro-anatomi telah mendapatkan penerapan ablasi kateter radiofrekuensi (RFCA) pada FA sebagai pilihan kuratif dalam praktek saat ini. Pengalaman sebelumnya menekankan pentingnya pencitraan atrium kiri dan vena pulmonalis sebelum dilakukan prosedur ablasi. Metode pencitraan telah menunjukkan bahwa anomali vena pulmonalis dapat mempersulit ablasi kateter sehingga mengakibatkan kesulitan prosedural dan mungkin berhubungan dengan angka kekambuhan. Penelitian pertama telah membuktikan bahwa ablasi kateter dapat menyembuhkan FA dengan berbagai teknik yang telah berevolusi. Sebuah pendekatan baru untuk isolasi lengkap dari posterior atrium kiri, termasuk semua vena pulmonalis dikaitkan dengan tingkat keberhasilan yang tinggi dari penanganan FA. Namun, untuk FA persisten cara tersebut mungkin tidak cukup, sehingga tambahan ablasi di lokasi kompleks atrium diperlukan untuk meningkatkan keberhasilan klinis. ${ }^{8}$

\section{SIMPULAN}

Fibrilasi atrium merupakan aritmia jantung yang paling umum berkelanjutan dan merupakan faktor risiko kematian yang paling sering dan dapat mencetuskan gejala iskemik pada kasus dengan dasar penyakit jantung koroner. Pada fibrilasi atrium terjadi depolarisasi yang menyebar ke segala arah di atrium. Walaupun gelombang depolarisasi tersebut kecil dan lemah, malah beberapa di antaranya memiliki polaritas yang berlawanan sehingga saling meniadakan, fibrilasi atrium merupakan keadaan yang memerlukan penanganan yang tepat dan segera.

\section{DAFTAR PUSTAKA}

1. Sudoyo AW, Setiyohadi B, Alwi I, Simadibrata KM, Setiati S, editor. Buku Ajar Ilmu Penyakit Dalam Jilid III (Edisi IV). Jakarta: FKUI, 2009; p.1537-42.

2. Guyton, Arthur C, Hall JE. Buku Ajar Fisiologi Kedokteran (Edisi IX). Jakarta: EGC, 1997; p.133-202.

3. Satomi K. Electrophysiological characteristic of atrial fibrilation tachycardia after pulmonary vein isolation of atrial fibrilation. Circulation. 2010;74(1):1051-8.

4. Bers DM. Cardiac action potential and ion channels. In: Excitation Contraction Coupling and Cardiac Contractile Force (Second Edition). Dordrecht: Kluwer Academic Publishers, 2001; p.63.

5. Cameron JR, Skofronic JG. Electrical signals from the heart - the electrocardiogram. In: Medical Physics. Florida: A Wiley-Interscience Publication, 1978; p.197.

6. Grant RM, Skofronick JG, Cameron JR. Sinyal listrik dari jantung Elektrokardiogram. In: Fisika Tubuh Manusia. Jakarta: EGC, 2006; p.213.

7. Matsue Y, Suzuki M, Abe M, Oho M, Seya M, Nakamura $T$, et al. Endothelial dysfunction in paroxysmal atrial fibrilation as a prothrombic state. Journal of Atherosclerosis and Thrombosis. 2011;18(2):298-304.

8. Kumaigai K. Catheter of ablation atrial fibrilation. Circulation. 2011;75(1): 2305-11. 